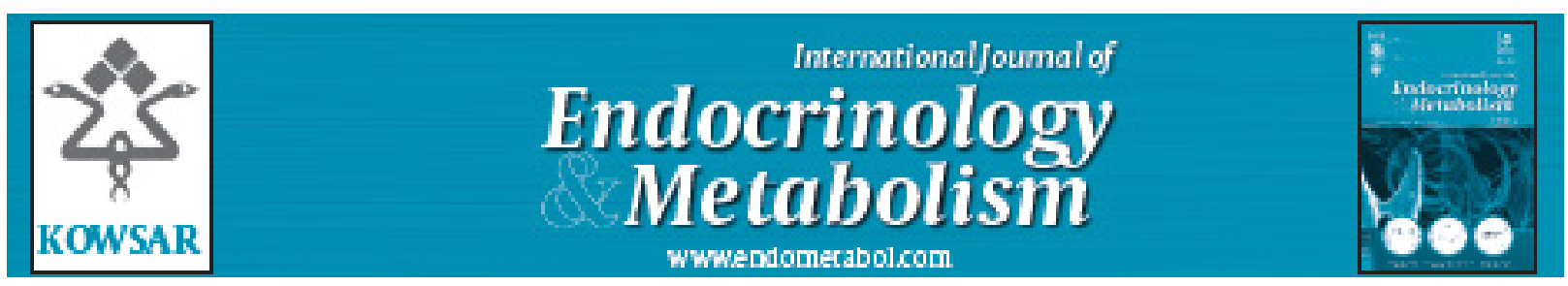

\title{
Potential Therapeutic Effects of Nitrate/Nitrite and Type 2 Diabetes Mellitus
}

\author{
Asghar Ghasemi ${ }^{1}$, Saleh Zahediasl ${ }^{*}, 1$ \\ ${ }^{1}$ Endocrine Physiology Research Center, Research Institute for Endocrine Sciences, Shahid Beheshti University of Medical Sciences, Tehran, IR Iran \\ ${ }^{*}$ Corresponding author Saleh Zahediasl, Endocrine Physiology Research Center, Research Institute for Endocrine Sciences, Shahid Beheshti University of \\ Medical Sciences, No. 24, Parvaneh St., Velenjak, P.O. Box:19395-4763., Tehran, IR Iran. Tel.:+98-2122432500, Fax:+98-2122402463, E-mail:zahedi@endocrine. \\ ac.ir.
}

Keywords: Diabetes; Nitrate; Nitrite

Approximately 285 million people worldwide had diabetes mellitus in 2010, 90\% of whom had Type 2 diabetes, and it is expected to rise to 439 million by 2030 (1). Currently although insulin and oral ant diabetic agents are used for treatment of diabetes, most of them usually have inadequate efficacy and adverse effects and therefore new strategies need to be examined (2). Type 2 diabetes is a complex metabolic disease and decreased beta-cell mass, beta-cell dysfunction, and increased insulin resistance have been reported to be important in its pathogenesis; however abnormal pulsatility of basal insulin secretion, loss of first-phase of insulin release, and increased glucagon secretion also contribute to the development of type 2 diabetes $(3,4)$. Nitric oxide (NO) is a simple ubiquitous molecule that plays important roles in almost every biological system (5). NO is synthesized from L-arginine by NO synthase (NOS) enzymes including endothelial (eNOS), neuronal (nNOS), inducible (iNOS), and mitochondrial (mtNOS) NOS. Approximately 90\% of
NO in the body is converted to nitrate, which is the main stable end-product of NO in vivo (5).

Inorganic nitrate (NO3-) and nitrite (NO2-) mostly considered as potentially harmful constituents in our food and drinking water $(6,7)$. According to WHO guidelines, upper limits for nitrate and nitrite are $50 \mathrm{mg} / \mathrm{L}$ and 3 $\mathrm{mg} / \mathrm{L}$ respectively and the sum of the ratios of the concentration of each to its guideline value should not exceed $1(8)$. The view that nitrate and nitrite are harmful is now being questioned after NOS-independent NO formation from nitrate and nitrite, was reported in 1994 (9); it seems that nitrate-nitrite-NO pathway is complementary or even a back-up system (mostly during hypoxia and low $\mathrm{pH}$ ) to the classical L-arginine-NO synthase pathway (7). Recent reports show that nitrate and nitrite may have some therapeutic and nutritional implications $(5,7)$ including protecting against ischaemia-reperfusion injury in mice (10), decreasing blood pressure in humans $(11,12)$ and animals (13), reducing oxidative stress (7), improved

Article type: Editorial; Received:12 Nov 2012, Revised: 11 Feb 2013, Accepted: 12 Feb 2013; DOI: 5812/ijem.9103

-Implication for health policy/practice/research/medical education:

New strategies need to be examined for treatment of type 2 diabetes. Current evidences show that nitrate/nitrite therapy could be considered as a new treatment for type 2 diabetes, however further researches are needed to explore the issue.

Please cite this paper as:

Ghasemi A, Zahediasl S. Potential Therapeutic Effects of Nitrate/Nitrite and Type 2 Diabetes Mellitus. Int J Endocrinol Metab. 2013;11(2):63-4. DOI:5812/ijem.9103

Copyright (C) 2013, Research Institute For Endocrine Sciences and Iran Endocrine Society; Published by Kowsar Corp.

This is an Open Access article distributed under the terms of the Creative Commons Attribution License (http://creativecommons.org/licenses/by/3.0), which permits unrestricted use, distribution, and reproduction in any medium, provided the original work is properly cited. 
mitochondrial efficiency due to reduced uncoupling in humans (14), and reducing oxygen consumption during exercise, which may improve physical capacity in disease with limited pulmonary function (7). It has been suggested that reduced NO availability is a central event in the pathogenesis of metabolic syndrome (15) and 10-week inorganic nitrate therapy reduces visceral fat accumulation, lowers serum triglycerides in eNOS deficient mice, and normalizes a disturbed glucose tolerance (16). These findings may have implications in prevention and treatment of type 2 diabetes (15) considering that long-term nitrate therapy also reduces weight gain $(16,17)$. In addition, L-arginine can evoke insulin release and it seems that NO may be physiologically involved in the release of insulin (18).

These potential therapeutic effects should however be considered in the context of reports on the harmful effects of nitrite/nitrate and L-arginine; induced NO formation may play a role in the destruction of the pancreatic beta cells during development of type 1 diabetes in mice (18). NO donors have been also shown to cause $\beta$ cell dysfunction and damage through IL-1 $\beta$ (19). In fact, NO causes FFA-induced decreased insulin secretion in prediabetic rat islets (19); iNOS is involved in the development of muscle insulin resistance in diet-induced obesity by affecting PI 3-kinase and Akt in mice (20) and the iNOS mRNA was 20 times higher in diabetic rats (19). High levels of plasma nitrate increase arterial pressure (21) and nitrate may cause early onset of hypertension and increased incidence of diabetes (6). In addition nitrate may induce kidney dysfunction (17) and long-term nitrate therapy, at least in animal studies, may produce hypothyroidism (17). Cancer, particularly of the stomach, is another concern attributed to nitrate (5); nitrate acts as a precursor in the formation of N-nitroso compounds, which are carcinogens in animals (22); however no causative link between nitrite and nitrate exposure and cancer including stomach cancer has been documented in humans $(5,23)$

In conclusion, there is a dichotomy of current scientific attitudes about the use of nitrate and nitrite; i.e. having potential new therapeutic application for human health or having potential human risks and further researches are needed in this field, especially to identify individuals that may benefit from nitrate/nitrite therapy. It seems that nitrate/nitrite therapy would be potentially beneficial, especially when derived from natural sources such as vegetables.

\section{Acknowledgements}

The authors wish to thank Ms N. Shiva for critical editing for English grammar and syntax of the manuscript.

\section{Financial Disclosure}

None declared.

\section{References}

1. Chen L, Magliano DJ, Zimmet PZ. The worldwide epidemiology of type 2 diabetes mellitus--present and future perspectives. Nat Rev Endocrinol.2012;8(4):228-36

2. Srinivasan K, Ramarao P. Animal models in type 2 diabetes research: an overview. Indian J Med Res.2007;125(3):451-72

3. Gastaldelli A. Role of beta-cell dysfunction, ectopic fat accumulation and insulin resistance in the pathogenesis of type 2 diabetes mellitus. Diabetes Res Clin Pract.2011;93 Suppl 1:S60-5

4. Ismail-Beigi F. Pathogenesis and glycemic management of type 2 diabetes mellitus: a physiological approach. Arch Iran Med.2012;15(4):239-46

5. Ghasemi A, Zahediasl S. Is nitric oxide a hormone? Iran Biomed J.2011;15(3):59-65

6. Powlson DS, Addiscott TM, Benjamin N, Cassman KG, de Kok TM, van Grinsven $\mathrm{H}$, et al. When does nitrate become a risk for humans? JEnviron Qual.2008;37(2):291-5

7. Weitzberg E, Lundberg JO. Dietary nitrate - a slow train coming. Physiol.2011;589(Pt 22):5333-4

8. World Health Organization. Guidelines for drinking-water quality. Geneva 2008

9. Ghasemi A, Zahediasl S. Preanalytical and analytical considerations for measuring nitric oxide metabolites in serum or plasma using the Griess method. Clin Lab.2012;58(7-8):615-24

10. Bryan NS, Calvert JW, Elrod JW, Gundewar S, Ji SY, Lefer DJ. Dietary nitrite supplementation protects against myocardial ischemiareperfusion injury. Proc Natl Acad Sci U S A.2007;104(48):19144-9

11. Larsen FJ, Ekblom B, Sahlin K, Lundberg JO, Weitzberg E. Effects of dietary nitrate on blood pressure in healthy volunteers. $N$ Engl Med.2006;355(26):2792-3

12. Webb AJ, Patel N, Loukogeorgakis S, Okorie M, Aboud Z, isra S, et al. Acute blood pressure lowering, vasoprotective, and antiplatelet properties of dietary nitrate via bioconversion to nitrite. $\mathrm{Hy}$ pertension.2008;51(3):784-90

13. Carlstrom M, Persson AE, Larsson E, Hezel M, Scheffer PG, Teerlink T, et al. Dietary nitrate attenuates oxidative stress, prevents cardiac and renal injuries, and reduces blood pressure in saltinduced hypertension. Cardiovasc Res.2011;89(3)

14. Larsen FJ, Schiffer TA, Borniquel S, Sahlin K, Ekblom B, Lundberg JO, et al. Dietary inorganic nitrate improves mitochondrial efficiency in humans. Cell Metab.2011;13(2):149-59

15. Lundberg JO, Carlstrom M, Larsen FJ, Weitzberg E. Roles of dietary inorganic nitrate in cardiovascular health and disease. Cardiovasc Res.2011;89(3):525-32

16. Carlstrom M, Larsen FJ, Nystrom T, Hezel M, Borniquel S, Weitzberg $\mathrm{E}$, et al. Dietary inorganic nitrate reverses features of metabolic syndrome in endothelial nitric oxide synthase-deficient mice. 2010;107(41):17716-20

17. El-Wakf AM, Hassan HA, El-said FG, El-Sai A. Hypothyroidism in Male Rats of Different Ages Exposed to Nitrate Polluted Drinking Water. Res J Med Med Sci2009;4(2):160-4

18. Anggard E. Nitric oxide: mediator,murderer, and medicine. Lancet.1994;343(8907):1199-206

19. Shimabukuro M, Ohneda M, Lee Y, Unger RH. Role of nitric oxide in obesity-induced beta cell disease. J Clin Invest.1997;100(2):290-5

20. Perreault M, Marette A. Targeted disruption of inducible nitric oxide synthase protects against obesity-linked insulin resistance in muscle. Nat Med.2001;7(10):1138-43

21. Zeballos GA, Bernstein RD, Thompson CI, Forfia PR, Seyedi N, Shen W, et al. Pharmacodynamics of plasma nitrate/nitrite as an indication of nitric oxide formation in conscious dogs. Circulation.1995;91(12):2982-8

22. Ward MH, deKokTM, Levallois P, Brender J, Gulis G, Nolan BT. Workgroup report: Drinking-water nitrate and health--recent findings and research needs. Environ Health Perspect.2005;113(11):1607-14

23. Bryan NS, Alexander DD, Coughlin JR, Milkowski AL, Boffetta P. Ingested nitrate and nitrite and stomach cancer risk: an updated review. Food Chem Toxicol.2012;50(10):3646-65 